University of Massachusetts Amherst

ScholarWorks@UMass Amherst

Chemistry Department Faculty Publication Series

Chemistry

2000

\title{
Determination of cadmium by flow injection- chemical vapor generation-atomic absorption spectrometry
}

C Vargas-Razo

JF Tyson

Follow this and additional works at: https://scholarworks.umass.edu/chem_faculty_pubs

Part of the Chemistry Commons

\section{Recommended Citation}

Vargas-Razo, C and Tyson, JF, "Determination of cadmium by flow injection-chemical vapor generation-atomic absorption spectrometry" (2000). FRESENIUS JOURNAL OF ANALYTICAL CHEMISTRY. 1049.

Retrieved from https://scholarworks.umass.edu/chem_faculty_pubs/1049 


\section{Cesar Vargas-Razo $\cdot$ Julian F. Tyson \\ Determination of cadmium by flow injection-chemical vapor generation-atomic absorption spectrometry}

Received: 15 May 1999 / Revised: 20 September 1999 / Accepted: 22 September 1999

\begin{abstract}
A method was developed for the generation of a "cold vapor" of cadmium by means of flow injectionchemical vapor generation from aqueous samples, the determination being conducted with an atomic absorption spectrometer (Pyrex glass T-cell). Several gas-liquid separator designs, atomizer designs, and the effect of several reagents previously reported as sensitivity enhancers (including cobalt, nickel, thiourea and didodecyl-dimethylammonium bromide) were investigated. The limit of detection, calculated as the concentration giving a signal equal to three times the standard deviation of the blank, was $16 \mathrm{ng} \mathrm{L}^{-1}$, and the relative standard deviation was $1.4 \%$ for a concentration of $2 \mu \mathrm{g} \mathrm{L}^{-1}$ and $3.8 \%$ for $0.1 \mu \mathrm{g}$ $\mathrm{L}^{-1}$. The addition of nickel and thiourea to the samples provided improved tolerance to the interference of coexisting ions. Two NIST certified reference materials, Montana Soil and Apple Leaves (respectively containing $41.7 \pm 0.25 \mathrm{mg} \mathrm{kg}^{-1} \mathrm{Cd}$ and $0.013 \pm 0.002 \mathrm{mg} \mathrm{kg}^{-1} \mathrm{Cd}$ ) were accurately analyzed. The interference of lead was overcome by coprecipitation with barium sulfate, and the experimental values obtained were $41 \pm 1 \mathrm{mg} \mathrm{kg}^{-1} \mathrm{Cd}$ and $0.013 \pm 0.002 \mathrm{mg} \mathrm{kg}^{-1} \mathrm{Cd}$, respectively.
\end{abstract}

\section{Introduction}

Cadmium is widely dispersed in the environment, and exposure to this element gives rise to accumulation in several organs in the body, with consequent adverse health effects. Even at low exposure levels $\left(\mathrm{mg} \mathrm{kg}^{-1}\right)$, the risk of renal tubular damage due to industrial exposure to cadmium can be considerable [1]. In addition, epidemiological studies are providing increasing evidence that this element is carcinogenic and exposures should be controlled to the lowest level possible [2]. There is a need for meth-

C. Vargas-Razo $\cdot$ J. F. Tyson ( $\varangle)$

Department of Chemistry, Box 34510,

University of Massachusetts, Amherst, MA 01003-4510, USA

e-mail: tyson@chem.umass.edu ods for the determination of $\mathrm{Cd}$ in a variety of matrices which are simple, rapid, accurate and have low detection limits.

For a limited number of elements, including As, Bi, $\mathrm{Ge}, \mathrm{Se}$ and $\mathrm{Sb}$, methods with these characteristics have been devised based on the atomic spectroscopic detection of atoms formed by the decomposition of the volatile hydrides of these elements generated by reaction of an acidified sample solution with an alkaline solution of sodium (or potassium) tetrahydroborateIII (commonly referred to as borohydride) [3]. The HG reaction is carried out in one of two ways: either in a batch reactor or in a flow system. The hydride is separated from the bulk solution by the hydrogen formed by the decomposition of the excess borohydride, and an added argon stream, and transported to the atomic spectrometer. The most widely used technique is AAS with atomization in a flame- or electrically-heated quartz tube. There is a growing number of reports of determinations by AAS following trapping of the volatile derivative on the interior surface of a graphite furnace atomizer [4].

Reaction with borohydride has also been used to generate volatile derivatives for the determination of other elements including $\mathrm{Cd}, \mathrm{Cu}, \mathrm{Hg}, \mathrm{Pb}, \mathrm{P}, \mathrm{Sn}$ and $\mathrm{S}$. In the case of $\mathrm{S}$, the limited number of reports concern the determination based on the molecular absorption of $\mathrm{H}_{2} \mathrm{~S}$ [5]. So far there is only one report on the generation of a volatile copper compound [6], the growing literature relating to the determination of lead has been reviewed recently [7], and there is a vast literature describing the determination of $\mathrm{Hg}$ by the so-called "cold vapor" method [8], though many of these procedures use $\mathrm{Sn}(\mathrm{II})$ as the reagent for production of $\mathrm{Hg}^{0}$.

Cacho et al.[9] first reported the determination of $\mathrm{Cd}$ by $\mathrm{HG}$ atomic spectrometry, although the identity of the volatile precursor of the atoms in the heated quartz tube atomizer was not unambiguously specified. The derivative was produced by the addition of borohydride in DMF to an acidic slution of $\mathrm{Cd}$ diethyldithiocarbamate $(\mathrm{Cd}-$ DDC) in dimethylformamide (DMF). Sanz-Medel and coworkers reported the determination of $\mathrm{Cd}$ by ICP-OES 
following generation of a volatile derivative by reaction with borohydride in an organized medium of didocyl-dimethylammonium bromide vesicles (DDAB) [10]. They subsequently discovered that the derivative spontaneously decomposed to atoms which had sufficiently long lifetimes to be measured by AAS at room temperature [11, 12]. This rather unexpected finding was rapidly confirmed by Guo and Guo [13], Liu and Xu [14], and Kradtap [15]. Garrido and co-workers have developed procedures for the determination of $\mathrm{Cd}$ in waters [16], and sewage sludge by CV-AAS [17], and showed that the sensitivity of the determination was the same in the presence and absence of the surfactant didodecyl-methylammonium bromide. This CV-AAS procedure had been used with in-atomizer trapping for the determination of $\mathrm{Cd}$ in a number of environmental samples. Several different trapping procedures have been reported: on a surface produced by the removal of the pyrolytic graphite coating by sandpaper wrapped round a glass rod [18], on an iridiumtungsten- or zirconium-coated graphite surface [19], and on a palladium-coated graphite surface [20,21].

Methods for the HG determination of Cd by AFS [22], and ICP-MS [23], have also been reported, as have several procedures in which the volatile ethyl derivative was produced by reaction with tetraethyl borate $[24,25]$.

There would appear to be considerable disagreement over the optimum conditions for the determination of cadmium by this $\mathrm{CV}$ procedure. In particular, conflicting results for the roles of various additives, such as surfactants and transition metals, have been obtained. There is also disagreement over the best procedure for removing the interference caused by a high concentration of lead in the sample.

We have sytematically studied the conditions for the determination of cadmium by FI-HG-AAS and in this paper we present the results of experiments for the optimization of manifold dimensions, reaction conditions and gas-liquid separation. Results are presented for the evaluation of: (a) the design of the gas-liquid separator (GLS), (b) the type of reducing reagent, (c) the dimensions and material for the atomization cell, (d) the effect of using an organized medium, and (e) the nature of the transfer line between the GLS and atomization cell. Results are also presented for a study of interferences, an evaluation of the role of organic reagents and some transition metal-ions as signal enhancers. On the basis of these experiments, procedures were devised for the determination of cadmium in soil containing a high concentration of lead, and in apple leaves.

\section{Experimental}

Instrumentation. A Perkin-Elmer (Norwalk, CT, USA) Model 3100 atomic absorption spectrometer was used as the detection unit. Various materials of different dimensions were used for the T-shaped atomization cell. The hollow-cathode lamp (Perkin Elmer) curreent was $3 \mathrm{~mA}$. The monochromator was set at $228.8 \mathrm{~nm}$ and $0.7 \mathrm{~nm}$ spectral bandpass. The instrument was operated with a PC computer using Perkin-Elmer GEM Desktop software. This

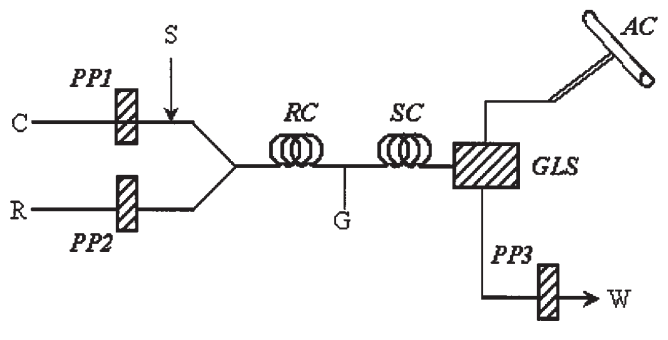

Fig. 1 Manifold for chemical vapor generation of cadmium. $P P 1$, $P P 2$ and $P P 3$, peristaltic pumps; $A C$, atomization cell; $G L S$, gasliquid separator; $R C$, reaction coil; $S C$, stripping coil; $C$, carrier solution $\left(0.48 \mathrm{~mol} \mathrm{~L}^{-1} \mathrm{HCl}\right) ; R$, borohydride $\left(0.9 \% \mathrm{~m} / \mathrm{v} \mathrm{NaBH}{ }_{4}\right.$ in $0.5 \% \mathrm{~m} / \mathrm{v} \mathrm{NaOH}$ ); $G$, carrier gas; $S$, sample; and $W$, waste

software does not include cadmium as an element for which hydride generation is an option, so that the default conditions for selenium were used as the starting point, and then (by modifying the selenium file), wavelength and current were set at the optimum values for cadmium. A problem with this procedure is that it is not possible to use background correction, because the intensity of the light from the deuterium lamp (automatically set for selenium) overpowers the intensity of the light from the cadmium hollow cathode lamp. The T-cell atomizer was positioned over the burner capable of supporting an air/acetylene flame, which was kept off for most of the experiments.

For evaluating the mass of cadmium transferred to the atom cell, a Perkin-Elmer SCIEX Elan 5000 inductively coupled plasma-mass spectrometer (Thornhill, Ontario, Canada) was used.

Manifold. A schematic diagram of the FI manifold is given in Fig. 1. PTFE tubing was $0.8 \mathrm{~mm}$ id up to the gas-liquid seperator (GLS). From the GLS to the atom cell, PTFE tubing of $1.5 \mathrm{~mm}$ id was used.

A six-port PTFE Rheodyne rotary valve (Supelco, Bellefonte, PA, USA) was used together with two Ismatec SA MS-Reglo Model 7331-10 peristaltic pumps (Cole-Parmer, Vernon Hills, IL, USA), one for the carrier line and the other for the borohydride and sample loop lines. The waste line from the GLS was pumped with a Lachat Instruments Model 1200-000 peristaltic pump (Milwaukee, WI, USA). The flow rates of all lines were regulated by controlling the rotation speed for the pump-head. Tygon pump tubing of $1.52 \mathrm{~mm}$ id (Cole-Parmer, Vernon Hills, IL, USA) was used in all experiments. The optimum conditions are given in Table 1 .

Apparatus. The four different GLSs used are shown schematically in Fig. 2. These consisted of a Perkin-Elmer design (part number B019-3772), a U-shaped PS Analytical (Orpington, Kent, UK) [26], a $30 \mathrm{~mL}$ Pyrex glass separation funnel, and a $5 \mathrm{~mL}$ lab-made Pyrex glass design. The drains from all the GLSs were pumped so that there was always a small portion of liquid remaining in the de-

Table 1 Optimized conditions

Chemical vapor generation

$\mathrm{HCl}$ concentration (carrier)/mol L-1

0.48

$\mathrm{NaBH}_{4}$ concentration/\% m/v

0.9

$\mathrm{HCl}$ concentration (sample)/mol L ${ }^{-1}$

0.19

Carrier flow rate $/ \mathrm{mL} \mathrm{min}^{-1}$

4.1

$\mathrm{NaBH}_{4}$ flow rate/mL min ${ }^{-1}$

2.9

Reaction coil length/cm

60

Stripping coil length/cm

60

Distance GLS-atomization cell/cm

20

Volume of sample/ $\mu \mathrm{L}$

300

Argon flow rate/mL min ${ }^{-1}$ 


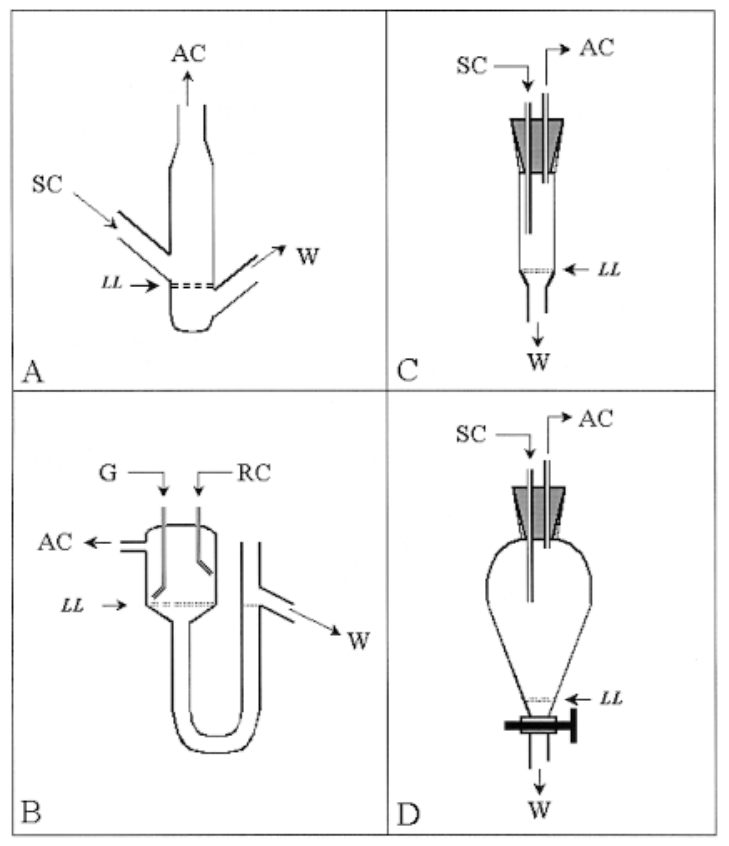

Fig. 2 Designs used for GLS. (A) Perkin-Elmer design (ca. $4 \mathrm{~mL}$ ), (B) PS Analytical (ca. $15 \mathrm{~mL}$ ), (C) Laboratory made (Pyrex glass, $5 \mathrm{~mL}$ ), and (D) Separation funnel $(30 \mathrm{~mL}) . S C$, from stripping coil; $R C$, from reaction coil; $A C$, to atomization cell; $G$, carrier gas; and $W$, to waste. $L L$ indicates the level of liquid maintained in the GLS (figures not to scale)

vice to avoid loss of analyte through the waste line (see LL marks in Fig. 2). For the U-shaped GLS, the reaction mixture entered the phase separator directly from the reaction coil, and the carrier gas was introduced directly to the GLS. The Perkin-Elmer GLS was used without glass beads.

Atomization T-cells were constructed from three different materials: quartz, Pyrex glass, and Lucite. Cells $10 \mathrm{~cm}$ long and $8 \mathrm{~mm}$ id were made from each material, and cells of Pyrex glass $10 \mathrm{~cm}$ long and 4 and $6 \mathrm{~mm}$ id were also made.

A Nafion dryer tube Model MD-250 (PermaPure, Toms River, NJ, USA) was connected between the GLS and the atomizer cell in some experiments.

To facilitate the dissolution of DDAB, a Vibracell Sonicator model VC50S equipped with an ASI high intensity ultrasonic probe was used (both from Sonics and Materials Inc., Danbury, CT, USA).

For the microwave digestion of the samples, a CEM (Indian Trail, NC, USA) Model MSD-81D microwave oven providing $630 \pm 70 \mathrm{~W}$ output power at $100 \%$ power setting was used. The 12 -vessel turntable drive system rotates the samples within the microwave field at $6 \mathrm{rpm}$. The vessels body and cap are made of polyetherimide, and the $100-\mathrm{mL}$ inner liner, cover and rupture membrane are made of Teflon-perfluoralkoxy (PFA). The vent screw is constructed of PTFE.

Reagents. All reagents were of analytical-reagent grade, or better. Deionized water (18 M $\Omega \mathrm{ms}$ ) was used for all experiments.

Carrier solutions were prepared from concentrated analytical grade hydrochloric acid (Fisher, Fairlawn, NJ, USA), which was also used to acidify the samples. For the samples, an appropriate volume of the same concentrated reagent was added to achieve concentration of $0.19 \mathrm{~mol} \mathrm{~L}^{-1} \mathrm{HCl}$.

For sample dissolution, hydrogen peroxide 30\% (Fisher), hydrofluoric acid 35\% (EM Science, Gibbstown, NJ, USA), and nitric acid $63 \%$ (Fisher) were used.

A solution $5 \% \mathrm{v} / \mathrm{v}$ dimethyldichlorosilane (Supelco, Bellefonte, PA, USA) in toluene (Fisher) was used to silanize the glass surfaces of the gas liquid separator.
Sodium borohydride solutions were prepared daily by dissolving appropriate amounts of the solid $\mathrm{NaBH}_{4}$ (Alfa-Aesar, Ward Hill, MA, USA) in $0.5 \% \mathrm{~m} / \mathrm{v}$ sodium hydroxide solutions. Sodium hydroxide (Fisher). Potassium borohydride (Fisher) solutions were prepared in the same way.

A concentration of $0.01 \mathrm{~mol} \mathrm{~L}^{-1}$ didodecyldimethylammonium bromide, DDAB (Eastman Kodak, Rochester, NY, USA), in the samples was obtained by adding the solid reagent to the sample, sonicating at a power of $60 \mathrm{~W}$ for $15 \mathrm{~min}$ with the tip of a high intensity ultrasonic probe and diluting to an appropriate volume.

A thiourea solution $(5 \% \mathrm{~m} / \mathrm{v})$ was prepared from the solid (Eastman Kodak). Lower concentrations were obtained by dilution.

A barium nitrate solution $(5 \% \mathrm{~m} / \mathrm{v})$ and a sodium sulfate solution $(5 \% \mathrm{~m} / \mathrm{v})$ were prepared from the solid salts (Fisher).

All cadmium solutions were prepared from a stock standard solution (Fisher) of $1000 \mathrm{mg} \mathrm{L}^{-1} \mathrm{Cd}$ in $1 \% \mathrm{HNO}_{3}$.

A solution $100 \mathrm{mg} \mathrm{L}^{-1} \mathrm{Ni}$ was prepared by dissolving a suitable mass of $\mathrm{NiCl}_{2}$ (Fisher) in water. Concentrations of 1, 10, 100, $1000 \mu \mathrm{g} \mathrm{L}^{-1} \mathrm{Ni}$ in the samples were obtained by dilution.

Solutions of the metal ions used for the interference study were prepared from stock standard solutions $1000 \mathrm{mg} \mathrm{L}^{-1}$ (Fisher), when available, or by dissolving the chloride or nitrate salts (Fisher) in water to obtain standards of $5000 \mathrm{mg} \mathrm{L}^{-1}$.

Sample pre-treatment. Two NIST reference materials, SRM 2711 Montana Soil and SRM 1515 Apple Leaves were utilized for method validation. Microwave-assisted digestions were performed in closed vessels.

For the Montana Soil approximately $0.1000 \mathrm{~g}$ of sample was weighed into a Teflon-PFA liner and $3 \mathrm{~mL}$ concentrated $\mathrm{HNO}_{3}$ and $1 \mathrm{~mL}$ concentrated HF were added. Four vessels (three replicates and a reagent blank) were sealed and irradiated at $40 \%$ power for $10 \mathrm{~min}$. After cooling to room temperature in a fume hood, the pressure was carefully released. If dissolution was not complete, the sample was irradiated for a further $10 \mathrm{~min}$ (40\% power). The clear solution was transferred to a PTFE crucible and gently heated to near dryness. After cooling, $10 \mathrm{~mL}$ of deionized water and $9.5 \mathrm{~mL}$ of $1 \mathrm{~mol} \mathrm{~L}^{-1} \mathrm{HCl}$ were added, followed by gentle heating until a clear solution was obtained. After cooling, the solution was transferred to a $50 \mathrm{~mL}$ calibrated flask, and $1.0 \mathrm{~mL}$ of $5 \%(\mathrm{~m} / \mathrm{v})$ $\mathrm{Na}_{2} \mathrm{SO}_{4}$ solution and $1.0 \mathrm{~mL} 5 \%(\mathrm{~m} / \mathrm{v}) \mathrm{Ba}\left(\mathrm{NO}_{3}\right)_{2}$ solution were added. After precipitation was complete, the precipitate was separated by centrifugation and $10 \mathrm{~mL}$ of a solution containing $5 \% \mathrm{~m} / \mathrm{v}$ thiourea and $0.5 \mathrm{~mL}$ of a solution containing $1.0 \mathrm{mg} \mathrm{L}^{-1}$ nickel were added, producing final concentrations of thiourea and nickel of $1 \%$ and $10 \mu \mathrm{g} \mathrm{L}^{-1}$, respectively.

Approximately $0.2000 \mathrm{~g}$ of the Apple Leaves SRM were soaked in $5 \mathrm{~mL}$ of concentrated nitric acid and $3 \mathrm{~mL}$ of $30 \% \mathrm{H}_{2} \mathrm{O}_{2}$ in a PTFE crucible. After the initial reaction was complete, the crucible was gently heated on a hot plate for $2 \mathrm{~h}$, until a clear solution was obtained. After gently heating to near dryness, and after a slow cooling, $10 \mathrm{~mL}$ of deionized water and $4.25 \mathrm{~mL}$ of $1 \mathrm{~mol} \mathrm{~L}^{-1} \mathrm{HCl}$ was added, followed by gently heating until a clear solution was obtained. After cooling, the solution was transferred to a $25 \mathrm{~mL}$ calibrated flask and thiourea and nickel solutions were added to achieve final concentrations of $1 \% \mathrm{~m} / \mathrm{v}$ and $10 \mu \mathrm{g} \mathrm{L}^{-1}$, respectively.

\section{Method development}

\section{Optimization of parameters}

The multi-cycle alternating variable search (MAVS) method was used for the optimization of the following parameters [27]: $\mathrm{HCl}$ concentration in the sample (0 to $\left.0.5 \mathrm{~mol} \mathrm{~L}^{-1}\right), \mathrm{NaBH}_{4}$ concentration $(0.1$ to $2.0 \% \mathrm{~m} / \mathrm{v})$, and $\mathrm{HCl}$ concentration in carrier (0 to $\left.1.2 \mathrm{~mol} \mathrm{~L}^{-1}\right)$; flow rates for carrier stream $\left(1.0\right.$ to $\left.6.0 \mathrm{~mL} \mathrm{~min}^{-1}\right)$, borohydride 


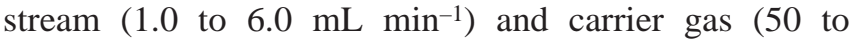
$700 \mathrm{~mL} \mathrm{~min}-1)$; and length for the reaction and stripping coils (30 to $200 \mathrm{~cm}$ ). The sample volume was varied between 100 and $500 \mu \mathrm{L}$.

The design of the GLS limits the reaction conditions in terms of flow-rates and reagent concentrations: high concentrations producing a vigorous reaction may interfere with the phase separation and gas transport stages. Four different designs of GLS were investigated.

It has been reported that the use of $\mathrm{KBH}_{4}$ enhanced sensitivity by 3-4 fold over that obtained with $\mathrm{NaBH}_{4}$ [18]. The performances of both reagents under conditions of equal molar concentrations were compared.

It has also been reported that the generation of the volatile cadmium species must be carried out in organic media to achieve the best sensitivity $[10-14,19,22]$. In addition, the use of some transition metals has been reported to increase the sensitivity by producing a catalytic effect $[13,14,22]$. The effect of the addition of $10^{-2} \mathrm{M}$ DDAB, $1.0 \% \mathrm{~m} / \mathrm{v}$ thiourea, and different concentrations of nickel and cobalt in the $\mu \mathrm{g} \mathrm{L}^{-1}$ range were studied. The species were investigated separately, as was a mixture of $1.0 \%$ thiourea and $10 \mu \mathrm{g} \mathrm{L} \mathrm{L}^{-1} \mathrm{Ni}(\mathrm{II})$.

Other parameters studied included the length and nature of the tubing between the GLS and atomization cell, the atomization temperature (flame on or off), and the nature and dimensions of the atomization cell. The role of the glass surface of the GLS was investigated for the $30 \mathrm{~mL}$ separating funnel, in which the interior surface was silanized with dimethyldichlorosilane to ensure total inertness of the glass surface [28].

Once an optimum design was found, the efficiency of a Nafion dryer in reducing the transfer of water vapor and droplets to the atomization cell was tested.

The figure of merit was peak height, as this is more sensitive to experiemntal variables than peak area. Precision was also measured. Peak shape was monitored and conditions which did not produce a single, well-formed peak for each injection were considered sub-optimal.

\section{Performance characteristics}

To determine the amount of cadmium transferred from the solution to the vapor phase into the atomization cell, an experiment was conducted in the continuous-flow mode with the optimized conditions shown in Table 1. The total mass of cadmium introduced into the manifold during $30 \mathrm{~s}\left(2 \mu \mathrm{g} \mathrm{L}^{-1} \mathrm{Cd}, 4.1 \mathrm{~mL} \mathrm{~min}^{-1}\right)$ was compared with the mass contained in the liquid collected from the waste line during the same time $(22 \mathrm{~mL})$, and the difference was taken as the amount transferred to the atom cell. The cadmium in the waste was determined with the ELAN 5000 ICP-MS instrument, calibrated externally with aqueous standards.

With the optimized set of experimental conditions, a calibration was constructed from five cadmium aqueous standards. The detection limit was calculated from data obtained from measurements of the blank $(0.19 \mathrm{M} \mathrm{HCl})$, from 5 replicates introduced before every standard was measured. The limit of detection was based on three times the standard deviation resulting from all the absorbance values obtained for the blank. Precision was evaluated as the RSD of 5 replicate determinations.

The tolerance of the optimized procedure to several metal ions in the absence and presence of thiourea and nickel was investigated. As lead severely interfered, this element was removed from the solution by coprecipitation with $\mathrm{BaSO}_{4}[13,14]$. The accuracy was evaluated by the determination of cadmium in two NIST reference materials: SRM 2711 Montana Soil, and SRM 1515 Apple Leaves. The method of standard additions was used $\left(0,0.4,0.8\right.$, and $1.2 \mu \mathrm{g} \mathrm{L}^{-1}$ in the case of SRM 2711 and $0.0 .2,0.4$, and $0.8 \mu \mathrm{g} \mathrm{L}^{-1}$ in the case of SRM 1515). Five replicate injections of each solution were made.

\section{Results and discussion}

Initial conditions were taken from previous results in our research group [15]. After the first set of experiments it was found that a concentration of $10 \mu \mathrm{g} \mathrm{L}^{-1}$ was sufficient for the optimization studies, producing a peak height of approximately 0.35 absorbance. It was also observed that by keeping the flame off (i.e. by working at room temperature) better results were obtained. Without the flame, the transient peaks were approximately three times larger than those obtained with the flame on. This observation is in agreement with the results obtained by Sanz-Medel and co-workers $[11,12]$. Therefore, all subsequent experiments were performed with the atom cell at room temperature.

\section{Atom cell}

There is convincing evidence that the species responsible for the absorption of radiation at $228.8 \mathrm{~nm}$ is "cold" atomic cadmium vapor, possibly produced by the decomposition of unstable $\mathrm{CdH}_{2}$ [12]. Therefore, it is expected that the atomization cell plays no role in the atomization process, and as a consequence, an active surface (such as that of the quartz cell used in the atomization of arsine and hydrogen selenide) is not required. For the cells made of quartz and Pyrex glass, a similar response was obtained, while the Lucite cell produced a significantly smaller signal. This difference may be due to partial trapping of the analyte vapor on the Lucite cell. Therefore, it seems that

Table 2 Effect of reducing internal diameter of a $10 \mathrm{~cm}$ Pyrex glass atomization cell. Experimental conditions as in Table 1

\begin{tabular}{lll}
\hline $\begin{array}{l}\text { Internal diameter } \\
(\mathrm{mm})\end{array}$ & $\begin{array}{l}\text { Average peak height } \\
(n=5)\end{array}$ & RSD \% \\
\hline 8 & 0.528 & 3.7 \\
6 & 0.549 & 2.8 \\
4 & 0.627 & 3.7 \\
\hline
\end{tabular}


the cell only provides a physical reservoir for the detection of cadmium atoms and has no role in the production of gas phase atoms. Moreover, it was noted that the response with the quartz cell decreased over time while that of the Pyrex cell remained unchanged. Pyrex glass cells were used in all further experiments.

Cells with different internal diameter were fabricated and evaluated. The results are shown in Table 2. The $4 \mathrm{~mm}$ id T-cell provided a signal approximately 20\% higher than that of the $8 \mathrm{~mm}$ id cell. However, as the internal diameter was decreased the amount of light passing through the cell became smaller, so that the signal to noise ratio decreased. Also, when using $4 \mathrm{~mm}$ the effects of water droplets accumulating in the cell were much more severe, and it was necessary to clean the cell often during the course of an experiment. For these reasons the $6 \mathrm{~mm}$ id atom cell was selected.

\section{Use of a Nafion dryer}

Small amounts of water vapor were transferred to the atom cell, which eventually condensed to give a droplet which partially obscured the light path. When the Nafion dryer was connected between the GLS and the atom cell to remove any moisture [29], the signal disappeared completely, presumably because cadmium was retained by the Nafion membrane. As only small amounts of liquid are transferred to the atom cell, droplet formation may be avoided by removing the atom cell from the spectrometer for manual cleaning. Moreover, as Pyrex glass cells are inexpensive and readily fabricated, it is possible to have extra cells available for regular replacement.

\section{Gas-liquid separation}

As it is considered that the gas-liquid separation is crucially important in obtaining the best sensitivity for the overall process, several experiments were conducted in order to obtain optimum separation and transfer of the analyte-vapor to the T-cell.

To verify the inertness of the glass surfaces towards the atomic vapor of cadmium being generated, two $30 \mathrm{ml} \mathrm{sep-}$ aration funnels, as described in Fig. 2 (GLS), were used. The response obtained with a silanized GLS was almost identical to that of a regular Pyrex glass GLS, indicating that the reactivity of glass surfaces was not important.

The performance of four different designs of GLS was studied. The $5 \mathrm{~mL}$ lab-made GLS provided the maximum peak height and the best peak shape as it was large enough to avoid the interference of bubble formation on the transfer line to the atom cell, and small enough to minimize peak broadening. The $30 \mathrm{~mL}$ separation funnel was not affected by problems of bubble formation, but its larger volume produced a 50\% lower signal. The Perkin Elmer GLS also suffered from the bubble formation problem, and although a large signal was obtained, the random and continuous transfer of water vapor affected peak height and shape significantly. The U-shaped GLS provided almost no signal; at first, this was thought to be the result of its large volume and not having a sufficiently long reaction coil. However, increasing the length of the reaction coil did not improve the sensitivity. For this GLS no stripping coil was used since its design calls for the introduction of the reaction mixture directly from the reaction coil, with the argon carrier injected to the main body of the GLS as well. It is proposed that in addition to its large volume, the U-shaped GLS may provide conditions for the redissolution of the vapor cadmium species instead of promoting its separation from the liquid phase.

\section{Optimization of parameters}

Reaction conditions. The optimum conditions, obtained after three cycles of the alternating variable search, are given in Table 1. For $\mathrm{NaBH}_{4}$, a concentration of $0.9 \% \mathrm{~m} / \mathrm{v}$ was optimum (see Fig. 3). At concentrations greater than $1 \% \mathrm{~m} / \mathrm{v}$, peak shape was severely affected (multiple broad peaks were obtained) because of the very vigorous reaction conditions and the large amount of water transferred to the atom cell. The concentration $0.9 \% \mathrm{~m} / \mathrm{v}$ is four times lower than that reported by other authors $[12,13]$. It has been reported that $\mathrm{KBH}_{4}$ gave a 3-4 fold enhancement in sensitivity compared to that obtained with $\mathrm{NaBH}_{4}$ [18] . However, no difference in peak height was observed when the reagents were used at equal molar concentration and equal reaction conditions. The sensitivity gain reported by Matusiewicz and co-workers [18], may be due to the fact that the experimental conditions used for each reagent were different.

The results for the optimization of the $\mathrm{HCl}$ concentration in the carrier stream are shown in Fig. 4. An interesting difference between the results for peak height and

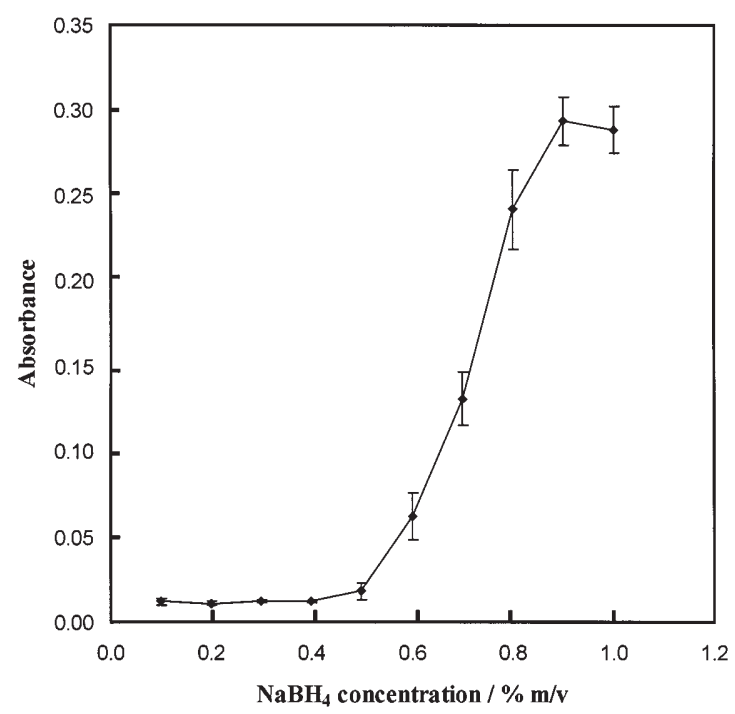

Fig. 3 Effect of concentration of $\mathrm{NaBH}_{4}$ on the signal peak height $10 \mu \mathrm{g} \mathrm{L}^{-1} \mathrm{Cd}$. Error bars represent standard deviation $(n=5)$. Other conditions shown in Table 1 

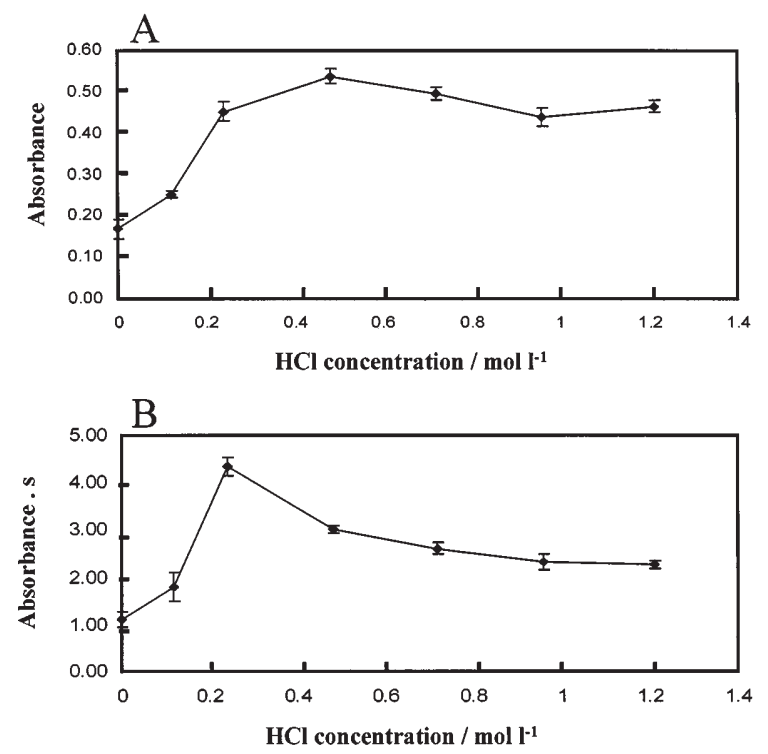

Fig. 4 Effect of concentration of $\mathrm{HCl}$ in carrier on the signal. (A) peak height, (B) peak area. $10 \mu \mathrm{g} \mathrm{L}^{-1} \mathrm{Cd}$. Error bars represent standard deviation $(n=5)$

peak area was obtained. For peak height, the signal was not significantly affected as the concentration of $\mathrm{HCl}$ was increased from 0.24 to $1.21 \mathrm{~mol} \mathrm{~L}^{-1}$, and for concentrations lower than $0.24 \mathrm{~mol} \mathrm{~L}^{-1}$ a sharp decrease in the signal was obtained. On the other hand, for peak area, a more significant increase in signal (approximately 2 -fold) was obtained at $0.24 \mathrm{~mol} \mathrm{~L}^{-1} \mathrm{HCl}$, as compared with that obtained for higher concentrations of acid. However, peak shape was poor, and as the relative standard deviation was always lower for peak height measurements, it was decided to use a concentration of $0.48 \mathrm{~mol} \mathrm{~L}^{-1}$, for which the best peak height response was obtained.

The results obtained for the effect of the concentration of acid in the sample are shown in Fig. 5. It can be seen

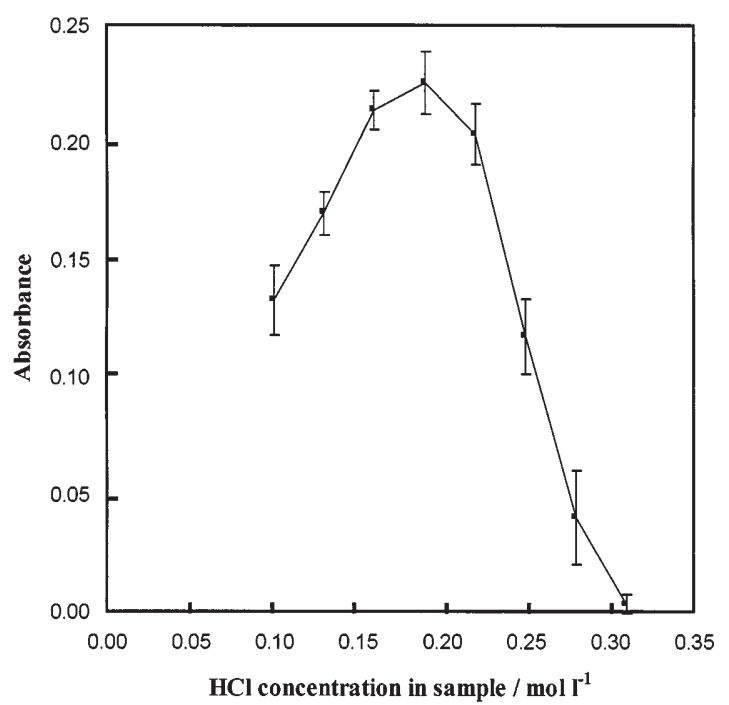

Fig. 5 Effect of concentration of $\mathrm{HCl}$ in sample on the signal. $2 \mu \mathrm{g}$ $\mathrm{L}^{-1} \mathrm{Cd}$. Error bars represent standard deviation $(n=5)$ that there is a very important dependence of the signal on this parameter, for which best response was obtained at $0.19 \mathrm{~mol} \mathrm{~L}^{-1} \mathrm{HCl}$. The optimum concentration of $\mathrm{HCl}$ in the carrier was about 2.5 times larger, and it appears that there is a significant role for an acid concentration gradient in the generation of the volatile species of cadmium.

The results for the studies of the effects of the flow rates of carrier and borohydride are shown in Fig. 6. A flow rate of $4.1 \mathrm{~mL} \mathrm{~min}^{-1}$ for the carrier was selected, because although the peak height was slightly higher at $3.6 \mathrm{~mL} \mathrm{~min}^{-1}$, the peak shape was less reproducible, so that precision was impaired. The results obtained for the flow rate of borohydride showed that although the best sensitivity was obtained at $3.9 \mathrm{~mL} \mathrm{~min}{ }^{-1}$, at this value the peak shape was not reproducible and a flow rate of $2.9 \mathrm{~mL} \mathrm{~min}^{-1}$ was selected as optimal.
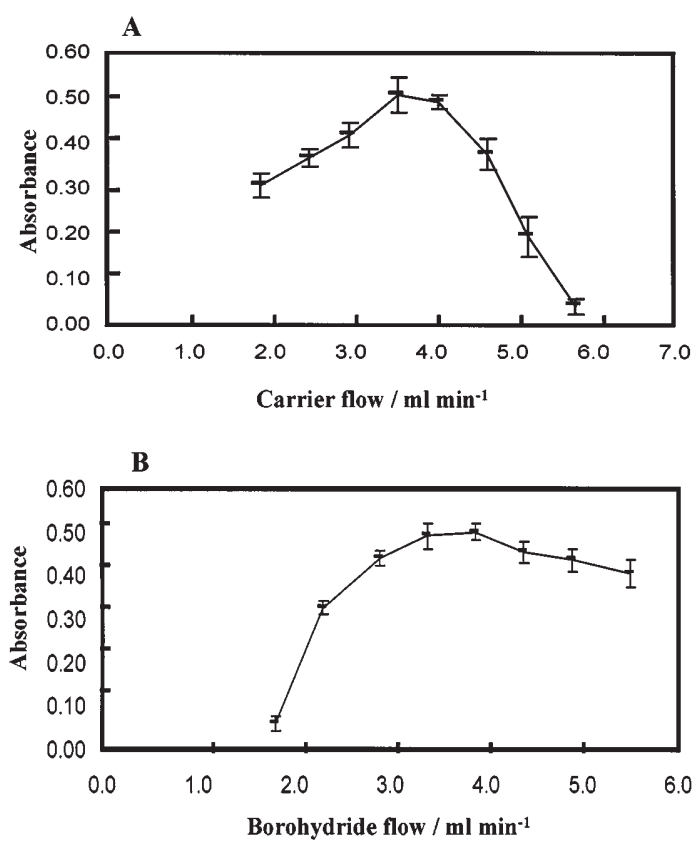

Fig. 6 Effect of flow rate of (A) carrier, and (B) borohydride, on the signal. $10 \mu \mathrm{g} \mathrm{L}^{-1} \mathrm{Cd}$. Error bars represent standard deviation $(n=5)$

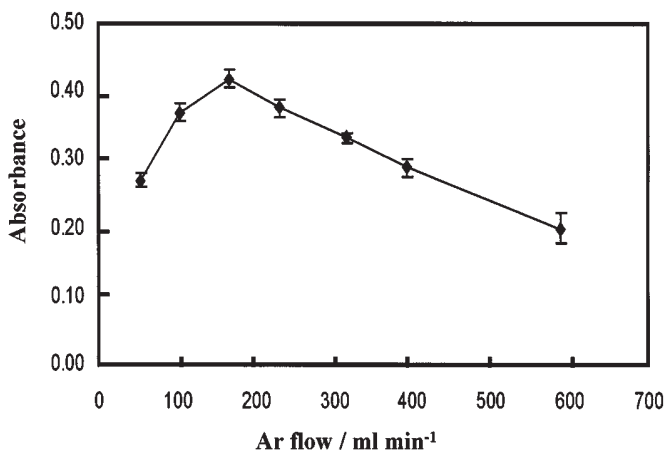

Fig. 7 Effect of carrier gas (argon) flow rate on the peak height of $2 \mu \mathrm{g} \mathrm{L}^{-1} \mathrm{Cd}$. Error bars represent standard deviation $(n=5)$. The gas liquid separator shown in Fig. 2C was used 
The dependence of the signal on the Ar flow rate used for the extraction of the vapor species in the stripping coil and transfer to the atom cell is shown in Fig. 7. A value of

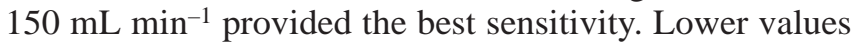
resulted in an inefficient transfer of the analyte vapor to the T-cell, as smaller peak heights were obtained, and higher values resulted in double peaks.

Manifold dimensions. Modifying the length of the reaction and stripping coils between 30 and $200 \mathrm{~cm}(0.8 \mathrm{~mm}$ i.d.) produced no significant effect on the signal. However, the length of tubing between the gas liquid separator and the T-cell (1.5 mm i.d.), had a significant effect. As this length was increased the signal decreased, so that the minimum length of tubing (approximately $20 \mathrm{~cm}$ ) must be used to obtain the best sensitivity. Finally, for the volume of analyte used, $300 \mu \mathrm{L}$ was selected as the optimum, since at lower volumes the signal decreased, and with higher volumes peak height did not increase further.

Under optimum conditions, the percentage of cadmium transferred from the solution to the detection cell was determined to be $92 \%$, based on the analysis of the waste solution with the ELAN 5000 plasma source mass spectrometer.

\section{Analytical performance}

Using the optimum set of experimental conditions in Table 1, a $5 \mathrm{~mL}$ lab-made GLS, which provided best results, and a Pyrex-glass T-cell (6 mm id), a calibration graph was constructed with solutions $0,0.2,0.5,1.0,1.5$, and $2.0 \mu \mathrm{g} \mathrm{L}^{-1}$ of $\mathrm{Cd}$. The equation of the linear calibration was $y=0.344( \pm 0.002) x+0.001( \pm 0.002)$ with $r=$
0.9994, where $y$ is peak height (absorbance), $x$ is concentration $\left(\mu \mathrm{g} \mathrm{L} \mathrm{L}^{-1}\right), r$ is correlation coefficient, and the \pm terms are $95 \%$ confidence interval values. The detection limit obtained was $10 \mathrm{ng} \mathrm{L}^{-1}$ and the precision was $1.4 \%$ for a cadmium concentration of $2 \mu \mathrm{g} \mathrm{\textrm {L } ^ { - 1 }}$.

Effect of organic species and organized media

It has been reported that the generation of cadmium volatile species must be carried out in organic media to achieve best sensitivity [10-14]. In addition, the use of some transition metals has been reported to produce an increase in sensitivity by means of a catalytic effect $[13,14$, 22]. No improvement in sensitivity was obtained when the reaction was carried out in a medium containing $10^{-2} \mathrm{~mol} \mathrm{~L}{ }^{-1} \mathrm{DDAB}$, or $1.0 \% \mathrm{~m} / \mathrm{v}$ thiourea. The results for DDAB agree with those reported by Garrido et al. [16]. However, for experiments in which thiourea $1.0 \%(\mathrm{~m} / \mathrm{v})$ and different concentrations of $\mathrm{Co}$ and $\mathrm{Ni}$ in the $\mu \mathrm{g} \mathrm{\textrm {L } ^ { - 1 }}$ range were added to the sample, an enhancement of the signal (of between 10 and 20\%) was observed. No significant difference in peak shape was observed. Considering the high transfer of $\mathrm{Cd}$ to the atom cell (92.1\%), adding an organic reagent or catalyst is not going to increase the transfer of cadmium to the atom cell in more than approx. $8 \%$, and the improvement obtained (10 to 20\%) is better explained as a result of better peak shape caused by the kinetic conditions of the thiourea-nickel medium. This confirms that nickel, in the presence of $1 \% \mathrm{~m} / \mathrm{v}$ thiourea, kinetically catalyze to some extent the formation of volatile species of cadmium by hydride generation.
Table 3 Effect of co-existing species on average peak height absorbance a $2 \mathrm{ng} \mathrm{mL}^{-1} \mathrm{Cd}$ in $0.19 \mathrm{M} \mathrm{HCl}$ b $2 \mathrm{ng} \mathrm{mL}^{-1} \mathrm{Cd}$ in $0.19 \mathrm{M} \mathrm{HCl}$ in the presence of $1.0 \% \mathrm{~m} / \mathrm{v}$ thiourea and $10 \mu \mathrm{g} \mathrm{L}^{-1} \mathrm{Ni}$

\begin{tabular}{lccll}
\hline Species & $\begin{array}{l}\text { Concentration } \\
\left(\mathrm{mg} \mathrm{L}^{-1}\right)\end{array}$ & $\begin{array}{l}\text { Concentration } \\
\text { ratio }\end{array}$ & Effect a & $\begin{array}{l}\text { Effect in presence } \\
\text { of Ni and thiourea }\end{array}$ \\
\hline $\mathrm{Ag}(\mathrm{I})$ & 0.1 & 50 & $-57 \%$ & $-39 \%$ \\
$\mathrm{Ba}(\mathrm{II})$ & 100 & 50000 & No effect & No effect \\
$\mathrm{Ca}(\mathrm{II})$ & 100 & 50000 & No effect & No effect \\
$\mathrm{Co}(\mathrm{II})$ & 1 & 500 & $-65 \%$ & $-48 \%$ \\
$\mathrm{Co}(\mathrm{II})$ & 0.1 & 50 & $-12 \%$ & $+24 \%$ \\
$\mathrm{Co}(\mathrm{II})$ & 0.01 & 5 & $+3 \%$ & $+15 \%$ \\
$\mathrm{Co}(\mathrm{II})$ & 0.001 & 0.5 & No effect & $+10 \%$ \\
$\mathrm{Cr}(\mathrm{III})$ & 1 & 500 & $-24 \%$ & No effect \\
$\mathrm{Cu}(\mathrm{II})$ & 0.1 & 50 & $-47 \%$ & $-36 \%$ \\
$\mathrm{Fe}(\mathrm{III})$ & 1 & 500 & $-50 \%$ & $-18 \%$ \\
$\mathrm{Hg}(\mathrm{II})$ & 1 & 500 & No effect & No effect \\
$\mathrm{Mg}(\mathrm{II})$ & 100 & 50000 & No effect & No effect \\
$\mathrm{Mn}(\mathrm{II})$ & 1 & 500 & $+4 \%$ & $+8 \%$ \\
$\mathrm{Ni}(\mathrm{II})$ & 1 & 500 & $-95 \%$ & $-68 \%$ \\
$\mathrm{Ni}(\mathrm{II})$ & 0.1 & 50 & $-46 \%$ & $-26 \%$ \\
$\mathrm{Ni}(\mathrm{II})$ & 0.01 & 5 & $+15 \%$ & $+16 \%$ \\
$\mathrm{Ni}(\mathrm{II})$ & 0.001 & 0.5 & No effect & No effect \\
$\mathrm{Pb}$ (II) & 0.1 & 50 & $-52 \%$ & $-49 \%$ \\
$\mathrm{~Pb}$ (II) & 0.01 & 5 & $-13 \%$ & $-15 \%$ \\
$\mathrm{Zn}$ (II) & 1 & 500 & $-38 \%$ & $-32 \%$ \\
\hline & & & &
\end{tabular}


Table 4 Analysis of standard reference materials by standard additions

\begin{tabular}{llll}
\hline Sample $^{\mathrm{a}}$ & $\begin{array}{l}\text { Certified value } \\
\left(\mathrm{mg} \mathrm{kg}^{-1}\right)\end{array}$ & $\begin{array}{l}\text { Value found without using } \\
\text { Ni and thiourea }\left(\mathrm{mg} \mathrm{kg}^{-1}\right)^{\mathrm{b}}\end{array}$ & $\begin{array}{l}\text { Value found using Ni and } \\
\text { thiourea }\left(\mathrm{mg} \mathrm{kg}^{-1}\right)^{\mathrm{b}}\end{array}$ \\
\hline NIST SRM 2711 & & & \\
Montana Soil & $41.7 \pm 0.25$ & $41 \pm 2$ & $41 \pm 1$ \\
$\quad$ Samples 1 and 2 & $39 \pm 3$ & $42 \pm 1$ \\
Samples 3 and 4 & Slope of calibration: & Slope of calibration: \\
& $0.275 \pm 0.004$ & $0.343 \pm 0.002$ \\
Samples 1 and 2 & $0.284 \pm 0.006$ & $0.333 \pm 0.003$ \\
Samples 3 and 4 & & & \\
NIST SRM 1515 & $0.013 \pm 0.002^{\mathrm{c}}$ & & $0.013 \pm 0.002$ \\
Apple Leaves & $0.013 \pm 0.001$ & $0.013 \pm 0.002$ \\
Samples 1 and 2 & & $0.012 \pm 0.001$ & Slope of calibration: \\
Samples 3 and 4 & & Slope of calibration: & $0.348 \pm 0.004$ \\
Samples 1 and 2 & & $0.296 \pm 0.001$ & $0.349 \pm 0.005$ \\
Samples 3 and 4 & & $0.302 \pm 0.003$ & \\
\hline
\end{tabular}

\section{Effect of coexisting ions}

The results of this study are given in Table 3 . Species such as $\mathrm{Ag}(\mathrm{I}), \mathrm{Cu}(\mathrm{II}), \mathrm{Fe}(\mathrm{III}), \mathrm{Co}(\mathrm{II})$ and $\mathrm{Ni}(\mathrm{II})$ produce a very high interference effect, while $\mathrm{Ba}(\mathrm{II}), \mathrm{Ca}(\mathrm{II}), \mathrm{Cr}(\mathrm{III})$, $\mathrm{Hg}$ (II), $\mathrm{Mg}$ (II) and $\mathrm{Mn}$ (II) produce no effect at concentrations well in the ppm range. It has been reported $[13,14]$ that by carrying the reaction in the presence of some transition metal ions such as iron, cobalt and nickel, the sensitivity increased in a significant manner. The results obtained, shown in Table 3, do not show any significant increase and in some cases, $\mathrm{Fe}(\mathrm{III}), \mathrm{Ni}(\mathrm{II}), \mathrm{Co}(\mathrm{II})$ at $1 \mathrm{mg}$ $\mathrm{L}^{-1}$, a significant interferent effect was observed. Such effect is the expected from transition metal ions in a hydride generation reaction [18]. A black precipitate appeared in the reaction coil when $100 \mu \mathrm{g} \mathrm{L}^{-1}$ Co was used. In addition, Table 3 shows the results obtained for a study of interferences in the presence of thiourea $1.0 \%(\mathrm{~m} / \mathrm{v})$ and $10 \mu \mathrm{g} \mathrm{L}^{-1} \mathrm{Ni}$. It appears that as well as catalyzing the reaction the use of thiourea and $\mathrm{Ni}$ reduces interference from some coexisting ions in the sample.

It is important to notice that the interfering or catalyzing effect of nickel is highly dependent on its concentration. For concentrations below $0.01 \mathrm{mg} \mathrm{L}^{-1}$, a catalyzing effect is observed (i.e., reduction of the interference of a third ion species). Above this concentration, the presence of nickel significantly suppresses the production of the vapor species of cadmium.

Accuracy of the method

The results for the analysis of two SRMs are shown in Table 4. Two procedures were used: (a) standard additions for the samples as obtained from the digestion procedure, and (b) standard additions for samples to which thiourea $1 \%(\mathrm{~m} / \mathrm{v})$ and nickel $10 \mu \mathrm{g} \mathrm{L}^{-1}$ were added. The $95 \%$ confidence intervals about the determined values are based on the uncertainty in the intercept of the extrapolated plot and were calculated from equations given in the text by Miller and Miller [30]. The overlap between the $95 \%$ confidence intervals about the determined values and those given for the SRMs indicates that t-tests would show nonsignificant differences between the values determined and the certificate values. The sensitivity (evaluated as the slope of the calibration) in the absence of nickel and thiourea was 17-19\% lower in the case of the soil sample and $13-14 \%$ lower for the apple leaves samples (compared with the sensitivity obtained for aqueous standards). As seen in Table 3, thiourea and nickel do not reduce the
Table 5 Analysis of standard reference materials using the linear calibration with aqueous standards ${ }^{\mathrm{a}}$

${ }^{a}$ Equation of calibration: $\mathrm{Ab}-$ sorbance $=0.001 \pm 0.343[\mathrm{Cd}]$. Concentration of cadmium in $\mu \mathrm{g} \mathrm{L}^{-1}$

${ }^{\mathrm{b}}$ For both SRMs, samples 1 and 3 did not contain nickel and thiourea, samples 2 and 4 did ${ }^{c}$ The \pm terms are the $95 \%$ confidence interval values for the results

${ }^{\mathrm{d}}$ Information value, not certified

\begin{tabular}{|c|c|c|c|}
\hline Sample ${ }^{\mathrm{b}}$ & $\begin{array}{l}\text { Certified value } \\
\left(\mathrm{mg} \mathrm{kg}^{-1}\right)\end{array}$ & $\begin{array}{l}\text { Value found without using } \\
\mathrm{Ni} \text { and thiourea }\left(\mathrm{mg} \mathrm{kg}^{-1}\right)^{\mathrm{c}}\end{array}$ & $\begin{array}{l}\text { Value found using } \mathrm{Ni} \text { and } \\
\text { thiourea }\left(\mathrm{mg} \mathrm{kg}^{-1}\right)^{\mathrm{c}}\end{array}$ \\
\hline \multicolumn{4}{|l|}{ NIST SRM 2711} \\
\hline Montana Soil & $41.7 \pm 0.25$ & & \\
\hline Samples 1 and 2 & & $32 \pm 2$ & $41 \pm 2$ \\
\hline Samples 3 and 4 & & $31 \pm 2$ & $40 \pm 2$ \\
\hline \multicolumn{4}{|l|}{ NIST SRM 1515} \\
\hline Apple Leaves & $0.013 \pm 0.002^{\mathrm{d}}$ & & \\
\hline Samples 1 and 2 & & $0.010 \pm 0.006$ & $0.012 \pm 0.006$ \\
\hline Samples 3 and 4 & & $0.011 \pm 0.006$ & $0.012 \pm 0.006$ \\
\hline
\end{tabular}


interfering effect of lead, so that the coprecipitation step after digestion of the sample remained necessary for samples with a high lead content. However, by adding $1 \% \mathrm{~m} / \mathrm{v}$ thiourea and $10 \mathrm{mg} \mathrm{L}^{-1}$ nickel to the sample other interferences were minimized and the sensitivity was not significantly different from that obtained for pure standards.

The results for the determinations against the calibration for aqueous standards are shown in Table 5. It can be seen that in the absence of thiourea and nickel the values obtained were inaccurate; however, when thiourea and nickel were added then the values obtained were not significantly different from the certificate values. Again, the 95\% confidence intervals were calculated from the uncertainty in the fit of the line to the calibration points [30].

Garrido et al. [16] reported that the coprecipitation of lead with $\mathrm{BaSO}_{4}$ caused a loss in the cadmium signal. They developed a procedure for overcoming interferences based on the addition of potassium cyanide. Our results did not provide evidence of the coprecipitation of cadmium with barium sulfate, but showed that the procedure is adequate for the removal of lead. Moreover, the use of $\mathrm{KCN}$ raises a safety issue because of the possible production of toxic $\mathrm{HCN}$ vapour.

\section{Conclusions}

The flow injection-chemical vapor generation method described in this work was shown to be an effective approach for improving the sensitivity of AAS determinations of cadmium in aqueous samples. The detection limit of $10 \mathrm{ng} \mathrm{L}^{-1}$ is comparable to that $\left(12 \mathrm{ng} \mathrm{L}^{-1}\right)$ obtained for GFAAS [31], while slightly poorer than that of ICP-MS $\left(0.8 \mathrm{ng} \mathrm{L}^{-1}\right)$, for a dilute urine matrix [32], but somewhat better than that of ICP-MS (43 ng L-1) for a marine sediment matrix [33]. The determination of $\mathrm{Cd}$ in this latter matrix suffers from isobaric overlap problems, making accurate analysis difficult. For the optimized reaction conditions, a suitable design for the gas-liquid separator significantly improved the overall efficiency of cadmium transfer from the sample to the atom cell. The method is easily applied to the determination of cadmium in soil and agricultural samples, with excellent results in terms of accuracy and precision.

Acknowledgement Financial support from the National Autonomous University of Mexico (U.N.A.M.) for Mr. Cesar VargasRazo is gratefully acknowledged.

\section{References}

1. Binder S, Matte T (1993) J Am Med Assoc 269:1679-1681

2. Lauwerys RR, Bernard AM, Roels HA, Buchet JP (1994) Clin Chem 40:1391-1394

3. Dedina J, Tsalev DL (1995) Hydride Generation Atomic Absorption Spectrometry. Wiley, New York

4. Matusiewicz H, Sturgeon RE (1996) Spectrochim Acta B 51 : 377-397

5. Ebdon L, Hill SJ, Jameel M, Corns W, Stockwell PB (1997) Analyst 122:689-693

6. Sturgeon RE, Boyko LJ, Liu J, Luong VT (1996) Anal Chem 68: $1883-1887$

7. Madrid Y, Cámara C (1994) Analyst 119: 1647-1658

8. Clevenger WL, Smith BW, Winefordner JD (1997) Crit Rev Anal Chem 27: 1-26

9. Cacho J, Beltrán I, Nerin C (1989) J Anal At Spectrom 4: 661-669

10. Valdez-Hevia MC, Fernandez de la Campa MR, Sanz-Medel A (1995) J Anal At Spectrom 8:847-854

11. Sanz-Medel A, Fernandez de la Campa MR, Valdez-Hevia MC, Bordel N (1995) Anal Proc 32:49-54

12. Sanz-Medel A, Fernandez de la Campa MR, Valdez-Hevia MC, Bordel N (1995) Anal Chem 67:2216-2227

13. Guo XW, Guo XM (1995) J Anal At Spectrom 10:987-991

14. Liu M, Xu S (1997) Atom Spectrosc 18:195-203

15. Kradtap S (1996) M.S. thesis, Department of Chemistry, University of Massachusetts, Amherst

16. Garrido ML, Muñoz-Olivas R, Cámara C (1998) J Anal At Spectrom $13: 295-300$

17. Garrido ML, Muñoz-Olivas R, Cámara C (1998) J Anal At Spectrom 13:1145-1149

18. Matusiewicz H, Kopras M, Sturgeon RE (1997) Analyst 122 : 331-336

19. Bermejo-Barrera P, Moreda-Piñeiro J, Moreda-Piñeiro A Bermejo-Barrera A (1996) J Anal At Spectrom 11:1081-1087

20. Sanz-Medel A, Fernandez-Sanchez ML, Goenaga-Infante H (1996) J Anal At Spectrom 11:571-576

21. Sanz-Medel A, Fernandez-Sanchez ML, Goenaga-Infante H (1997) J Anal At Spectrom 12:1333-1339

22. Guo XW, Guo XM (1995) Anal Chim Acta 310:377-385

23. Hwang TJ, Jiang SJ (1997) J Anal At Spectrom 12:579-584

24. D'Ulivo A, Chen YW (1989) J Anal At Spectrom 2:349-354

25. Ebdon L, Goodall P, Worsfold PJ (1993) J Anal At Spectrom 5 :723-729

26. Cossa D, Sanjuan J, Cloud J, Stockwell PB, Corns WT (1995) J Anal At Spectrom 10:287-291

27. Greenfield S, Salman MS, Thomsen M, Tyson JF (1989) J Anal At Spectrom 4:55-61

28. Knapp R (1979) Handbook of Analytical Derivatization Reactions. Wiley, New York

29. Sundin NG, Tyson JF, Hanna CP McIntosh SA (1995) Spectrochim Acta B 50:369-375

30. Miller J, Miller JN (1993) Statistics for Analytical Chemistry, 3rd ed., Ellis Horwood, Chichester, pp 110-119

31. Chuang H, Huang SD (1994) Spectrochim Acta B 49:283-288

32. de Boer JLM, de Joode P, Ritsema R (1998) J Anal At Spectrom 13:971-975

33. Cook JM, Robinson JJ, Chenery SNR (1997) Analyst 122: $1207-1210$ 